DOI: https://doi.org/10.35387/ucj.1(3).2021.58-65

ТЕТЯНА БЛАГОВА

\title{
РОЗВИТОК ХОРЕОГРАФІЧНОЇ ОСВІТИ В УКРАЇНІ У СТРУКТУРІ НАВЧАЛЬНИХ ЗАКЛАДІВ КУЛЬТУРИ І МИСТЕЦТВА
}

\begin{abstract}
Анотація. Досліджено розвиток професійної хореографічної освіти в Україні у структурі навчальних закладів культури і мистецтва. На основі ретроспективного, системно-структурного та педагогічного аналізу з'ясовано, що інституційна хореографічна підготовка виконавських, балетмейстерських, культурно-просвітницьких та хореографічно-педагогічних кадрів в Украӥні актуалізована з другої половини XX століття. Вона реалізовувалася в різних типах навчальних закладів гуманітарного спрямування в різноманітті організаційних форм та освітніх ступенів. Метою публікації визначено дослідження нормативного забезпечення, стратегій, змістових напрямів підготовки хореографічних кадрів у структурі мистецької освіти в Україні. Професійну хореографічну освіту інтерпретовано як самостійну галузь мистецької освіти зі своєю структурою, інституційно оформленою у профільних закладах фахової передвищої та вищої школи. Теоретичне узагальнення джерельної бази дослідження дозволило виявити, що кожна ланка хореографічної освіти, підпорядковуючись загальним закономірностям розвитку мистецької освіти, мала свої цілі та завдання. Спрямованість змістового наповнення хореографічного навчання здобувачів варіювала в залежності від цільових настанов, кваліфікаційних характеристик обраної спеціальності, а також сфери їі практичного застосування у мистещькій та педагогічній галузях. Узагальнено, що хореографічна підготовка була спрямована на формування у майбутніх фахівців компетентностей, необхідних для успішної професійної самореалізації в якості керівника хореографічного колективу, організатора хореографічного аматорства, культорганізатора, методиста хореографічного жанру, педагогахореографа в різних типах культурно-просвітницьких закладів. Зазначено, що наступність і неперервність розвитку професійного та особистісного потенціалу фахівця у сфері хореографічної діяльності забезпечують різні форми підвищення кваліфікації, актуалізовані в умовах сьогодення.
\end{abstract}

Ключові слова: хореографічна освіта, хореографічна підготовка, навчальні заклади культури і мистецтва, культурно-просвітницький діяч, керівник хореографічного колективу, балетмейстер, педагог-хореограф.

\section{CHOREOGRAPHIC EDUCATION DEVELOPMENT IN UKRAINE IN THE STRUCTURE OF CULTURE AND ART EDUCATIONAL INSTITUTIONS}

\begin{abstract}
The development of professional choreographic education in Ukraine in the structure of specialize educational institutions of culture and art is investigated. Based on retrospective analysis, systemstructural and pedagogical analysis, it was found that the institutional choreographic training of performers, choreographers, cultural-educational and choreographic-pedagogical staff in Ukraine has been updated since the second half of the XX century. It was implemented in various types of humanitarian direction educational in a variety of organizational forms and degrees. The purpose of the publication is to analyze the regulatory framework, strategies, and content areas of training of training choreographic personnel in the structure of art education in Ukraine. Professional choreographic education is interpreted as an independent branch of art education with its own structure, institutionalized in the specialized institutions of professional higher and higher education. Theoretical analysis of the source base of the study revealed that each link of choreographic education, obeying the general laws of art education, had its own goals and objectives. The orientation of the content of choreographic training of applicants varied depending on the target guidelines, qualification characteristics of the chosen specialty, as well as the scope of its practical application in the artistic and pedagogical fields. It is generalized that choreographic training was aimed at forming in future specialists the competencies necessary for successful professional self-realization as a leader of choreographic team, organizer of choreographic amateur, cultural organizer, methodologist of choreographic genre, teacher-choreographer in different types of cultural and educational institutions. It is noted that the continuity and continuity of the development of professional and personal potential of a specialist in the field of choreographic activities provide various forms of professional development, relevant in today's conditions.

Key words: choreographic education, choreographic training, educational institutions of culture and art, cultural and educational figure, leader of the choreographic collective, choreographer, teacherchoreographer.
\end{abstract}


Вступ. Сучасний суспільний поступ інтеграції України до європейського співтовариства вимагає активної модернізації усіх ступенів та напрямів мистецької освітньої галузі. Зокрема, особливе місце в культурно-освітньому просторі сьогодення посідає фахова передвища та вища освіта мистецького профілю, сфокусована на підготовці фахівців, здатних до самостійного осмислення і креативного трактування художніх процесів і явищ, готових до неперервного особистісного і професійного зростання, соціальної і фахової мобільності. Вона $\epsilon$ діалектичним процесом, що реалізується в різних організаційних формах різних освітніх ступенів і напрямів. У цьому контексті професійну хореографічну освіту інтерпретуємо як самостійну галузь мистецької освіти зі своєю структурою, інституційно оформленою у профільних закладах фахової передвищої та вищої школи. Підпорядковуючись загальним закономірностям розвитку мистецької освіти, кожна їі ланка має свої цілі, специфічні завдання та характеристики. Формування змістових концептів хореографічної освіти $\epsilon$ багатоаспектною проблематикою в галузі педагогіки мистецтва, яка потребує узагальненого наукового аналізу і осмислення в умовах сьогодення. Цей факт потверджує важливість розширення комплексних історикопедагогічних розвідок у цій галузі.

Метою $є$ дослідження нормативного забезпечення, стратегій, змістових напрямів професійної підготовки хореографічних кадрів у структурі фахової передвищої та вищої мистецької освіти в Україні в історико-культурній динаміці.

Теоретичні основи та методи дослідження. Концептуальні засади розвитку хореографічної освіти висвітлено у працях відомих методологів професійної хореографії: Г. Березової, Є. Валукіна, К. Василенка, В. Вронського, К. Голейзовського, Ю. Григоровича, Ю. Громова, Р. Захарова, Ф. Лопухова, I. Смірнова, інших фахівців галузі. Деякі аспекти проблематики функціювання інституційної хореографічної освіти, її структурних рівнів, тенденцій і перспектив розвитку досліджені у сучасних наукових розвідках Л. Андрощук, С. Забредовського, Б. Кокуленка, Б. Колногузенка, В. Литвиненка, Л. Макарової, Т. Павлюк, О. Пархоменка, В. Похиленка, О. Ребрової, Т. Сердюк, Т. Філановської, Л. Цвєткової,
О. Шамрової, М. Юр'євої. Однак, серед наукових здобутків у зазначеній галузі малодослідженим аспектом залишається студіювання загальних тенденцій та закономірностей розвитку національної системи хореографічної освіти в діяльності її окремих інституційних форм, багатовекторних 3 огляду на спрямованість хореографічних спеціальностей і спеціалізацій. Ретроспективу специфіки їхнього організаційнопедагогічного досвіду вважаємо важливим задля процесу модернізації професійної підготовки майбутнього фахівця-хореографа у структурі сучасних освітніх інституцій культури і мистецтва.

Реалізація зазначеної мети зумовлює застосування низки наукових методів. Основою цілісного розгляду окресленої проблеми визначаємо методи системноструктурного та ретроспективний аналізу, що застосовувалися з метою окреслення комплексу організаційних, структурних та змістових аспектів професійної хореографічної освіти у навчальних закладах культури і мистецтва; уможливили виявлення особливостей функціювання професійної хореографічної освіти в історико-культурній динаміці. Педагогічний аналіз використовувався для характеристики змістового компоненту хореографічної підготовки здобувачів закладів культури і мистецтва, метод теоретичного узагальнення дозволив сформулювати висновки дослідження та перспективи впровадження прогресивних тенденцій розвитку професійної хореографічної освіти в умовах сьогодення.

Виклад основного матеріалу. Аналізуючи розвиток професійної хореографічної освіти в Україні, зазначимо, що інституційні форми фахової хореографічної підготовки були актуалізовані лише з другої половини XX ст. і превалювали в закладах гуманітарної освіти. Підготовку культурноосвітніх діячів різних профілів забезпечували спеціалізовані навчальні заклади, підпорядковані Комітету у справах мистецтв УРСР і Комітету у справах культурноосвітніх установ УРСР. Неукомплектованість галузі кваліфікованими кадрами стимулювала з другої половини ХХ ст. кількісну динаміку розвитку культурно-освітніх шкіл із одночасним розширенням спектру спеціальностей. Якщо станом на 1944-1945 н. р. функціювало 13 технікумів політосвіти, які готували бібліотекарів і працівників 
культурно-освітньої галузі (ЦДАВО України. Ф.4762. Оп. 1. Спр. 16. Арк. 1-7), то наприкінці 40-х рр. у технікумах (їхня кількість зросла вже до 16 із загальною кількістю студентів 3590 осіб (ЦДАВО України. Ф.4762. Оп. 1. Спр. 105. Арк. 293)) з'явилися нові відділення для підготовки масовиківвитівників та керівників усіх жанрів художньої самодіяльності. Актуальною стратегією розвитку галузі було визначено організацію в УРСР у найкоротший термін ще 9 технікумів політосвіти 3 тією метою, щоб у кожній області функціював заклад з підготовки культурно-освітніх працівників, насамперед керівників художньої самодіяльності, оскільки у цей період 3-поміж загальної кількості майбутніх культпросвітників у складі технікумів політосвіти на спеціальності «організатор художньосамодіяльних гуртків» навчалося лише 42 особи (ЦДАВО України. Ф. 4762. Оп. 1. Спр. 149. Арк. 47).

Популярність у соціумі танцювального жанру зумовлювала потребу у запровадженні інституційної підготовки культпросвітників, здатних забезпечувати хореографічну освіту в різних формах організації культурного дозвілля. Зокрема, проблема нестачі у закладах культури і мистецтва хореографів-методистів, хореографівінспекторів та хореографів-організаторів неодноразово була актуалізована під час республіканських заходів для працівників культурно-освітніх закладів. Упродовж 1946 р. Комітет у справах культурноосвітніх установ УРСР затвердив низку нормативів, спрямованих на посилення професійної підготовки кваліфікованих організаторських та керівних кадрів художньої самодіяльності, зокрема й тих, що були безпосередньо дотичні до процесу хореографічної освіти у культосвітній галузі. У Київському, Одеському, Львівському та Дніпропетровському технікумах політосвіти вже з початку 1946-1947 н. р. були організовані відділення художньої самодіяльності; при Київському та Одеському технікумах організовані заочні відділення для культосвітніх працівників, які не мали повної фахової освіти, та запроваджено проведення для студентів масових лекцій 3 фаху і культмасових заходів у позаурочний час з метою розширення їхнього професійного світогляду (Благова, 2020, с. 362).
Низка затверджених ініціатив спрямовувалася на покращення у технікумах політосвіти змісту вузькопрофільної підготовки, а саме: за сприяння Управління художньої самодіяльності спільно із Центральним Будинком народної творчості [далі ЦБНТ - Т.Б.] до початку 1946-1947 н. р. оновлено навчальні плани та відредаговано навчальні програми дисциплін з художньо-самодіяльної роботи; з метою забезпечення якісного викладання практикоорієнтованих дисциплін з методик клубної діяльності для викладачів технікумів організовано місячний навчальний семінар у м. Києві; для майбутніх організаторів художньо-самодіяльної роботи на базі ЦБНТ проведено семінар-практикум з фахових методик, а також актуалізовано курсову підготовку та перепідготовку культпросвітників в якості дієвої форми посилення їхньої інституційної освіти (ЦДАВО України. Ф. 4762. Оп. 1. Спр. 30. Арк. 52, 54, 56, 62). Незважаючи на запроваджені заходи, питання «укомплектованості закладів культури кваліфікованими працівниками з вищою i середньою фаховою мистецькою освітою залишалося актуальним. Про той факт, що керівниками самодіяльних хореографічних гуртків керують переважно молоді люди, які не мають спеціальної освіти, наголошувалося у звітній документації культосвітньої галузі. На необхідності реорганізації профільного навчання студентів у культосвітніх технікумах, його максимального наближення до виробничих умов і потреб вкотре зазначалося у стенограмах нарад діячів культурно-просвітницької роботи обласних та республіканського рівнів.

3 1948-1949 н.р. Міністерство Вищої освіти СРСР затвердило нові навчальні плани для «клубних» відділень культосвітніх навчальних закладів з метою вдосконалення прикладної підготовки студентів. Значних змін зазнали спецдисципліни. Аналіз навчальної документації технікумів кінця 40-х рр. дозволив зазначити, що ознайомлення майбутніх фахівців з основами хореографічної педагогіки було закладено у змісті дисциплін, які розкривали особливості методики клубної роботи, якот: «Основи культурно-просвітницької роботи», «Культурно-освітня робота», «Організація і методика клубної роботи». Однак, незважаючи на варіативність у назвах, змістове наповнення дисциплін було майже 
ідентичним і охоплювало різні аспекти клубної і, зокрема, хореографічної діяльності. У розділі «Робота клубів по комуністичному вихованню трудящих» було деталізовано специфіку професійної підготовки культпросвітників за напрямами: «Художнє виховання», «Роль мистецтва у комуністичному вихованні», «Позашкільне виховання дітей», «Організація культурного відпочинку і розваг», «Художня самодіяльність, різноманітність їі видів і жанрів», «Керівництво художньою самодіяльністю», «Хореографічна самодіяльність», «Колективи народного танцю» (Програма курсу «Культурно-освітня робота», 1951).

Наприкінці 40-х рр. у навчальні плани «клубних» відділень офіційно впроваджено факультативну дисципліну «Танцювальне мистецтво» 3 метою підготовки майбутніх керівників аматорських хореографічних колективів (ЦДАВО України. Ф. 4762. Оп. 1. Спр. 291. Арк. 12-21). Ії̈ зміст корелював зі змістом обов'язкового контенту вузькопрофільного навчання, а саме, з методиками організації клубної роботи та художньої самодіяльності. Про запровадження хореографічної дисципліни зазначено у звітах Київського, Дубнівського, Ніжинського, Теребовлянського, Тульчинського, Харківського, Чернівецького технікумів. Незважаючи на те, що дисципліна мала статус «факультативної», студенти вивчали їі нарівно 3 обов'язковими, а по закінченні курсу складали залік. У 1950-1951 н. р. для викладачів хореографії масовим тиражем було видано загальну навчальну програму з курсу «Танцювальне мистецтво» (ЦДАВО України. Ф. 4762. Оп. 1. Спр. 568. Арк. 24).

Формування практичних хореографічних навичок відбувалося також у форматі позааудиторної гурткової роботи обов'язкового складника організації навчально-виховного процесу в усіх культурно-просвітницьких технікумах. Хореографічна творчість майбутніх культпросвітників була характерною ознакою «клубних» гуртків, які об'єднували різні види самодіяльності. Однак, поступово ця тенденція зникає, оскільки у нормативах культосвітньої галузі з'являються постанови щодо доцільності організації гуртків за окремими напрямами мистецької активності, 3 метою прищеплення студентам смаку до майбутнього фаху. У підсумках навчальновиховної роботи культурно-освітніх техні- кумів за 1948-1949 н. р. указано про пожвавлення студентської гурткової творчості та демонстрацію її результатів під час проведення масових мистецьких вечорів (ЦДАВО України. Ф. 4762. Оп. 1. Спр. 291. Арк. 21).

У 60-ті рр., у контексті загальних перетворень у культурно-освітніх навчальних закладах, відбулися прогресивні зміни в організації хореографічної підготовки майбутніх культпросвітників, як-от: 1) поглиблення змісту хореографічних дисциплін та розширення напрямків хореографічного навчання; 2) підтримка гурткової хореографічно-самодіяльної роботи та підвищення професійних вимог до її проведення; 3) збільшення годин на проведення виробничих практик та організація їх на базі зразкових закладів культури і мистецтва, зокрема, відомих аматорських танцювальних колективів; 4) запровадження у технікумах хореографічної (клубно-хореографічної) спеціалізації; 5) організація методичних об'єднань (предметних комісій) 3 хореографічних дисциплін; 6) узагальнення й поширення передового досвіду роботи викладачів-хореографів шляхом видання й розповсюдження навчально-методичної літератури. Оптимізація хореографічного навчання у культурно-просвітницьких навчальних закладах середньої ланки була спричинена передовсім запровадженням 3 1960-1961 н. р. для майбутніх організаторів-методистів клубної роботи додаткової спеціалізації «керівник самодіяльного художнього колективу» (за видами мистецької діяльності, зокрема хореографічної) (ЦДАВО України. Ф. 5116. Оп. 12. Спр. 311. Арк. 66-77).

Важливо зазначити, що з-поміж закладів вищої освіти, які здійснювали навчальну й науково-дослідну роботу в галузі культурного будівництва, орієнтиром підготовки хореографічних кадрів в Україні в останню чверть XX ст. стає Київський державний інститут культури [тодішня назва Київського національного університету культури і мистецтв - Т.Б.]. За ініціативи знаного балетмейстера, педагога-хореографа К. Василенка, балетмейстера Г. Березової та вченого-фольклориста, мистецтвознавця А.Гуменюка з 1970 р. у закладі було започатковано професійну підготовку фахівців у галузі мистецтва танцю. Пріоритетним напрямом діяльності кафедри під керівницт- 
вом К. Василенка визначено професійнопрактичну підготовку керівників хореографічних колективів, організаторів хореографічної самодіяльності. До програмного змісту хореографічного навчання було запроваджено дисципліни «Український танець», «Народно-сценічний танець», «Методика роботи з самодіяльним танцювальним колективом», «Композиція та постановка танців», «Хореографічний ансамбль», «Історія хореографічного мистецтва», «Бальний танець», «Класичний танець», «Мистецтво балетмейстера» (Благова, 2020, с. 368). За ініціативи очільника кафедри К. Василенка в освітньо-виховний процес упроваджувалися також мистецькі навчальні дисципліни загальнокультурного спрямування: «Історія художньої культури», «Теорія музики та аналіз музичних творів», «Сценічне оформлення костюмів». Їхня функційність полягала у забезпеченні всебічної підготовки хореографічних кадрів (Жиров, 2007, с. 151). Викладачі хореографічних дисциплін використовували різні форми навчання, (групові лекційні та практичні, індивідуальні, факультативні, консультативні та секційні), презентували результати своєї діяльності у форматах академконцертів і творчих звітів, а також брали активну участь у загальноінститутських семінарах і конференціях. Від викладацького складу кафедри консультативну допомогу отримували керівники хореографічних самодіяльних колективів.

Поступово кафедра сформувалась у науково-практичний центр із розробки теоретичних досліджень та впровадження новаторських методик хореографічної освіти республіканського значення. На різних етапах функціювання кафедри діяльність відомих педагогів-хореографів, майстрів української сцени (Г. Боримської, В. Володько, Є. Зайцева, О. Касьянової, О. Колоска, В. Пасютинської, Ю. Станішевського, Л. Цвєткової) органічно поєднувалася з науково-дослідною роботою, спрямованою на розробку теорії і практики навчання в галузі професійної хореографії. Їхня плідна праця відкрила можливості для формування вітчизняної хореографічної педагогіки (Благова, 2020, с. 368).

Інституційна підготовка фахівцівхореографів, залишаючись актуальним напрямом розвитку культосвітньої галузі, поступово розширювалася за рахунок упровадження різних спеціальностей і спеціалізацій. У 1972 р. на базі декількох культурно-освітніх училищ для старшокурсників спеціальності 2004 «Культурно-просвітницька робота» були впроваджені «вузькі спеціалізації», затверджені галузевим міністерством і розподілені у мережі закладів так: у Львівському училищі - «керівник школи бального танцю», «керівник хореографічного фольклорного ансамблю»; у Херсонському училищі - «організатор культмасової та спортивної роботи 3 дітьми»; у Чернівецькому училищі - «організатор художньої самодіяльності»; у Хустському училищі - «масовик-витівник» (ЦДАВО України. Ф. 5116. Оп. 19. Спр. 651. Арк. 28-30). 31977 р. при Харківському інституті культури розпочав діяльність факультет підвищення кваліфікації викладачів спеціалізованих дисциплін культурноосвітніх училищ. 3-поміж інших спеціалізацій запроваджена «Хореографія», а у переліку спецдисципліни зазначалися «Танок» i «Композиція та постановка танцю» (ЦДАВО України. Ф. 5116. Оп. 19. Спр. 653. Арк. 3942).

Інституційні форми організації підготовки фахівців-хореографів для культосвітньої галузі корелювали з неформальними, унормованими профільним міністерством та хореографічним відділом РНМЦ. Вони впроваджувалися 3 метою продовження базової освіти випускників середніх і вищих навчальних закладів, поглиблення їхньої виконавської та педагогічної компетентностей. Поширеними формами перепідготовки були семінари-практикуми, короткострокові та постійні курси, стажування, науково-практичні конференції, консультації провідних діячів хореографічного мистецтва. Кожна із організаційних форм мала різні освітні програми, змістові характеристики, кадровий потенціал, але, на наше переконання, загалом вони забезпечували наступність і неперервність розвитку хореографічної освіти (Благова, 2020, c. 369-370).

Відповідно до держзамовлень на підвищення фахового рівня кадрів культурномистецької галузі Інститут підвищення кваліфікації працівників культури України забезпечував їхню щорічну перепідготовку, анонсуючи у «Календарному плані проведення занять» теми проблемного навчання, розраховані і на представників хореог- 
рафічних спеціальностей. Упродовж 1995 р. запроваджувалися «очно-заочні» форми навчання з тем, які охоплювали різні напрями хореографічної освіти: «Сучасний танець. Творча лабораторія» - для завідувачів хореографічними відділеннями шкіл мистецтв; «Народна хореографія: стан і перспективи розвитку» - для керівників народних хореографічних колективів, методистів з хореографії; «Організація культурно-дозвіллєвої діяльності» - для художніх керівників клубних установ; «Сучасна аматорська хореографія: проблеми, тенденції» - для керівників гуртків сучасного танцю; «Сучасні тенденції розвитку українського танцю» - для викладачів училищ культури; «Самодіяльні танцювальні колективи: стан і перспективи розвитку» - для керівників самодіяльних танцювальних колективів (ЦДАВО України. Ф. 5116. Оп. 19. Спр. 3275. Арк. 205-235).

301.09 .1993 р., за наказом Міністерство культури України № 93 від 21.04.1993 р., у мистецьких навчальних закладах середньої ланки запроваджено нові навчальні плани з підготовки молодших спеціалістів для різних мистецьких напрямів, зокрема й для спеціальності 0509 «Хореографічне мистецтво» (ЦДАВО України. Ф. 5116. Оп. 19. Спр. 3279. Арк. 306). У переліку кваліфікаційних характеристик і вимог до «фахівців групи культури та мистецтва», затверджених у 1993 р., зазначалися й такі, що потверджували важливість їхньої і мистецької, і загальнопедагогічної підготовки: «<...> керівник колективу художньої самодіяльності спрямовує навчально-виховну та художньо-творчу роботу на піднесення мистецького рівня й виконавської майстерності його учасників, <..> обирає ефективні форми й методи культурноосвітньої роботи <..> Постійно підвищує професійний рівень, педагогічну, виконавську майстерність, загальну культуру» (ЦДАВО України. Ф. 116. Оп. 18. Спр. 42. Арк. 152-154).

Розширення спектра хореографічних спеціальностей на ринку праці з початку XXI ст. спричинило диверсифікацію напрямів професійної підготовки хореографів в умовах закладів вищої освіти культури і мистецтва. Фактично цей процес реалізовувався в організації хореографічних кафедр чи факультетів, у структурі яких функціюють профільні кафедри різної спрямованості (класичної, народної, бальної, су- часної хореографії). Грунтовну підготовку фахівців хореографічних спеціальностей для різних типів навчальних закладів забезпечували, зокрема, Харківська державна академія культури (з 1989 р. - на кафедрі хореографії, з 2003 р. - на факультеті хореографічного мистецтва,), Державна академія керівних кадрів культури і мистецтва (з 1970 р. функціювала як Інститут підвищення кваліфікації працівників культури). Формування нових напрямів стилістики сценічного виконавського мистецтва наприкінці XX - 3 початку XXI ст. зумовлювало процеси осучаснення вимог до моделі підготовки кваліфікованого фахівця в сфеpi професійного танцю в різних типах культосвітніх навчальних закладів. Кожний новий чи оновлений напрям сценічнохореографічної творчості вимагав науковообгрунтованого методичного супроводу i шляхів його практичної реалізації (Благова, 2020, с. 373-374).

Наступним важливим етапом професійного зросту і самовдосконалення хореографа є продовження фахової базової освіти, оскільки профільні знання і практичні уміння навчати танцювальному мистецтву, отримані здобувачами у структурі фахового передвищого чи вищого навчального закладу, потребують свого подальшого розвитку, вдосконалення, разом із розширенням професійного світогляду, методичного мислення і методичних здібностей педагога-хореографа. Реалізація цього завдання, незалежно від вузькоспрямованого профілю професійної активності випускника, відбувається у різних формах перепідготовки, допідготовки, стажування, курсових заходів підвищення кваліфікації, а також в організації науково-практичних конференцій, семінарів і вебінарів, майстер-класів провідних діячів хореографічного мистецтва, конкурсних і концертних заходів (Blahova, 2019, с. 626). Загалом зазначена ланка хореографічної освіти забезпечує неперервність розвитку професійного та особистісного потенціалу фахівця у сфері хореографічної діяльності.

Висновки. В результаті дослідження хореографічної освіти в Україні в структурі навчальних закладів культури і мистецтва нами узагальнено особливості організації, нормативного забезпечення, змістових напрямів її розвитку в умовах різних організаційних форм та освітніх рівнів. Контент- 
аналіз освітнього процесу в зазначених типах професійних навчальних закладів гуманітарного профілю дозволив виявити загальні тенденції розвитку фахової хореографічної підготовки здобувачів, як-от: комплексність і професійно-практична спрямованість навчання; активна інтеграція здобувачів у виконавську і педагогічну практику; органічне поєднання формальних і неформальних форм організації. Професійна хореографічна освіта була спрямована на формування хореографічнопедагогічних та балетмейстерських компетентностей, необхідних для самореалізації у професійній хореографічній діяльності в якості виконавців, культорганізаторів, організаторів хореографічного аматорства, педагогів танцю, балетмейстерів.

Першочерговим завданням сучасної передвищої та вищої хореографічної освіти, незалежно від специфіки майбутньої професійної активності випускникахореографа, визначається формування йо- го конкурентоздатності на ринку праці. У результаті здійсненого аналізу структурнозмістових аспектів професійної хореографічної освіти також з'ясовано, що спрямованість профільного навчання варіює в залежності від цільової настанови, кваліфікаційних характеристик обраної спеціальності, а також сфери її практичного застосування у художньому виробництві. Актуальною в умовах сьогодення залишаються тенденції модернізації професійної підготовки майбутнього фахівця-хореографа в закладах спеціалізованої середньої та вищої освіти на основі компетентнісного підходу, збагачення хореографічної педагогіки інноваційними ідеями, впровадження сучасних хореографічно-педагогічних технологій у процес викладання професійноорієнтованих дисциплін. Перспективами напрямами подальшого розвитку хореографічної освіти вважаємо активну інтеграцію їі цілей, завдань, змістового компоненту у різних організаційних формах.

\section{ЛІТЕРАТУРА}

Благова, Т.О. (2020). Розвиток хореографічної освіти в Україні: історико-педагогічний концепт: монографія. Полтава:ТОВ: ACMI. (Blahova, T.O. Rozvytok khoreohrafichnoi osvity v Ukraini: istorykopedahohichnyi kontsept : monohrafiia. Poltava: TOV. ASMI.)

Годовой отчет о работе Управления художественной самодеятельности комитета и Центрального Дома народного творчества УССР за 1947 год. // ЦДАВО України. Ф. 4762. Оп. 1. Спр. 149. 49 арк. (Hodovoi otchet o rabote Upravlenyia khudozhestvennoi samodeiatelnosty komyteta y Tsentralnoho Doma narodnoho tvorchestva USSR za 1947 hod. // TsDAVO Ukrainy. F. 4762. Op. 1. Spr. 149. 49 ark.).

Докладные записки Комитета по делам культурно-просветительной работы УССР о состоянии работы культурно-просветительных учреждений УССР, направленные ЦК КП(б)У за 1947 год. Том 2. // ЦДАВО України. Ф. 4762. Оп. 1. Спр. 105. 306 арк. (Dokladnye zapysky Komyteta po delam kulturno-prosvetytelnoi raboty USSR o sostoianyy raboty kulturno-prosvetytelnykh uchrezhdenyi USSR, napravlennыe TsK KP(b)U za 1947 hod. Tom 2. // TsDAVO Ukrainy. F. 4762. Op. 1. Spr. 105.306 ark.).

Жиров, О.А. (2007). Розвиток української народної хореографії у мистецько-педагогічній спадщині та діяльності К. Василенка (50-90 роки XX cm.). (Дис. канд. пед. наук). Полтава. (Zhyrov, O. A. (2007). Rozvytok ukrainskoi narodnoi khoreohrafii u mystetsko-pedahohichnii spadshchyni ta diialnosti K. Vasylenka (50-90-ti roky XX stolittia) (Dys. kand. ped. nauk). Poltava.).

Листування з вищестоящими організаціями з питань відкриття нових учбових закладів, створення матеріальної бази за 1961 рік. // ЦДАВО України. Ф. 5116. Оп. 12. Спр. 311.95 арк. (Lystuvannia z vyshchestoiashchymy orhanizatsiiamy z pytan vidkryttia novykh uchbovykh zakladiv, stvorennia materialnoi bazy za 1961 rik. // TsDAVO Ukrainy. F. 5116. 0p. 12. Spr. 311.95 ark.).

Міністерство культури України. Накази №№ 507-561 міністра з основної діяльності 03 - 31 жовтня 1994 року. // ЦДАВО України. Ф. 5116. Оп. 19. Спр. 3275. 255 арк. (Ministerstvo kultury Ukrainy. Nakazy №№ 507-561 ministra z osnovnoi diialnosti 03 - 31 zhovtnia 1994 roku. // TsDAVO Ukrainy. F. 5116. Op. 19. Spr. 3275. 255 ark.).

Міністерство культури України. Накази №№ 613-673 міністра з основної діяльності 01 - 30 грудня 1994 року. // ЦДАВО України. Ф. 5116. Оп. 19. Спр. 3279. 187 арк. (Ministerstvo kultury Ukrainy. Nakazy №№ 613-673 ministra z osnovnoi diialnosti 01 - 30 hrudnia 1994 roku. // TsDAVO Ukrainy. F. 5116. 0p. 19. Spr. 3279.187 ark.).

Накази з основної діяльності Міністерства освіти України з № 288 по № 310, 1993 р. // ЦДАВО України. Ф. 166. Оп. 18. Спр. 42.185 арк. (Nakazy z osnovnoi diialnosti Ministerstva osvity Ukrainy z № 288 po № 310, 1993 r. // TsDAVO Ukrainy. F. 166. Op. 18. Spr. 42.185 ark.). 
Отчет о работе отдела учебных заведений Комитета по делам культурно-просветительной работы УССР за 1950-1951 учебный год. // ЦДАВО України. Ф. 4762. Оп. 1. Спр. 568. 24 арк. (Otchet o rabote otdela uchebnykh zavedenyi Komyteta po delam kulturno-prosvetytelnoi raboty USSR za 19501951 uchebnyi hod. // TsDAVO Ukrainy. F. 4762. Op. 1. Spr. 568. 24 ark.).

Приказы председателя Комитета по делам культурно-просветительных учреждений при Совете Народных Комиссаров УССР по основной деятельности за 1946 год. // ЦДАВО України. Ф. 4762. Оп. 1. Спр. 30. 250 арк. (Prykazy predsedatelia Komyteta po delam kulturno-prosvetytelnykh uchrezhdenyi pry Sovete Narodnykh Komyssarov USSR po osnovnoi deiatelnosty za 1946 hod. // TsDAVO Ukrainy. F. 4762. Op. 1. Spr. 30. 250 ark.).

Приказы №o 392-468, 470-509 Министерства культуры УССР по основной деятельности, 1977 р. // ЦДАВО України. Ф. 5116. Оп. 19. Спр. 651. 269 арк. (Prykazy №№ 392-468, 470-509 Mynysterstva kultury USSR po osnovnoi deiatelnosty, 1977 r. // TsDAVO Ukrainy. F. 5116. Op. 19. Spr. 651. 269 ark.).

Приказы №o 627-676 Министерства культуры УССР по основной деятельности, 1977 р. // ЦДАВО України. Ф. 5116. Оп. 19. Спр. 653. 196 арк. (Prykazy №№ 627-676 Mynysterstva kultury USSR po osnovnoi deiatelnosty, 1977 r. // TsDAVO Ukrainy. F. 5116. Op. 19. Spr. 653. 196 ark.).

Протоколы №№ 20-25 заседаний Комитета по делам культурно-просветительных учреждений при Совете Министров УССР и документы к протоколам за 1949 год. // ЦДАВО України. Ф. 4762. Оп. 1. Спр. 291. 150 арк. (Protokoly №№ 20-25 zasedanyi Komyteta po delam kulturno-prosvetytelnykh uchrezhdenyi pry Sovete Mynystrov USSR y dokumenty k protokolam za 1949 hod. // TsDAVO Ukrainy. F. 4762. Op. 1. Spr. 291. 150 ark.).

Програма курсу «Культурно-освітня робота». (1951). Для технікумів підготовки культурноосвітніх працівників. Харків: Вид-во Книжкової палати УРСР. (Prohrama kursu «Kulturno-osvitnia robota». (1951). Dlia tekhnikumiv pidhotovky kulturno-osvitnikh pratsivnykiv. Kharkiv: Vyd-vo Knyzhkovoi palaty URSR.).

Сводный отчет Комитета по делам культурно-просветительных учреждений УССР и отчеты техникумов подготовки культурно-просветительных работников об их работе за 1944-1945 учебн. год. // ЦДАВО України. Ф. 4762. Оп. 1. Спр. 16. 65 арк. (Svodnyi otchet Komyteta po delam kulturno-prosvetytelnykh uchrezhdenyi USSR i otchety tekhnykumov podhotovky kulturnoprosvetytelnykh rabotnykov ob ykh rabote za 1944-1945 uchebn. hod. // TsDAVO Ukrainy. F. 4762. Op. 1. Spr. 16.65 ark.).

Blahova, T. (2019). Formation of concepts of higher choreographic education in Ukraine. In Association Agreement: Driving Integrational Changes: Collective monograph (pp.617-628). Accent Graphics Communication. Chicago, Illinois, USA.

Тетяна Благова, доктор педагогічних наук, доцент, завідувач кафедри хореографії Полтавського національного педагогічного університету імені В.Г. Короленка.

Tetiana Blahova, Doctor of Sciences in Pedagogy, Associate Professor, the Head of Department of Choreography, V.G. Korolenko Poltava National Pedagogical University.

E-mail: tatablagova@gmail.com ORCID ID 0000-0001-5446-3412

Received: 04.10.2021

Accepted: 25.10.2021 